\title{
SIKAP SISWA MADRASAH DINIYAH TERHADAP PEMBATASAN PEMBELAJARAN AGAMA MASA PANDEMIK
}

\author{
Sarbini \\ UIN Sunan Gunung Djati Bandung \\ Email: sarbini@uinsgd.ac.id
}

\begin{abstract}
Abstrak
Tulisan ini ingin mengetahui dampak pembatasan terhadap pembelajaran Pendidikan agama pada masa pandemi COVID-19 bagi aktivitas sehari-hari siswa madrasah. Kebijakan dari pemerintah terkait pembatasan kegiatan pembelajaran memiliki tujuan memutus mata rantai penyebaran Covid-19. Kajian ini menggunakan pendekatan kualitatif dengan memanfaatkan penggalian data secara wawancara mendalam dan studi kelompok terfokus atau Focus Group Discussion. Temuan studi ini antara lain: Pertama, siswa madrasah menerima dan mematuhi secara penuh kebijakan pemerintah terkait pembatasan pembelajaran. Kedua, adanya kebijakan new normal, membuat sikap siswa menjadi berragam dimana muncul Sebagian siswa yang memiliki sikap kurang patuh terhadap aturan yang diberlakukan. Ketiga, kepatuhan terhadap pembatasan pembelajaran dipengaruhi oleh keyakinan secara ideologis tentang takdir. Kajian ini menyimpulkan bahwa sikap siswa madrasah terhadap pembatasan pembelajaran memiliki ragam bentuk, yakni ada yang adaptif, persuasive, dan antipati.
\end{abstract}

Kata Kunci: Sikap, Siswa Madrasah, Kebijakan Publik, Pandemi Covid-19.

\begin{abstract}
This paper wants to know the impact of restrictions on religious education learning during the COVID-19 pandemic on the daily activities of madrasa students. The government's policy regarding the limitation of learning activities has the aim of breaking the chain of spread of Covid-19. This study uses a qualitative approach by utilizing data mining through in-depth interviews and focus group studies. The findings of this study include: First, madrasah students fully accept and comply with government policies regarding learning restrictions. Second, there is a new normal policy, which makes students' attitudes diverse, where some students have a less obedient attitude to the rules that are enforced. Third, adherence to learning restrictions is influenced by ideological beliefs about destiny. This study concludes that the attitudes of madrasah students towards learning restrictions have various forms, namely adaptive, persuasive, and antipathetic.
\end{abstract}

Keywords: Attitude, Students of Madrasah, Government Policy, Pandemic Covid-19.

\section{A. PENDAHULUAN}

Siswa madrasah merupakan peserta didik yang secara pembelajaran lebih banyak belajar tentang ilmu agama. yang hidup tentunya tidak terlepas dari berbagai aktivitas guna memenuhi kebutuhan hingga kepentingannya. Kebutuhan fisik maupun spiritual menjadi aspek utama agar kehidupan berjalan dengan seimbang. Terlebih pada masyarakat beragama, salah satu pemenuhan kebutuhan spiritual yang perlu dilakukan yakni belajar agama. Selain 
daripada dasar yang menyatakan bahwa belajar agama adalah perintah Tuhan, sebagai manusia tentunya membutuhkan ketenangan dalam hidup. Ketenagan ini kemudian dikonvensasikan ke dalam suatu bentuk tata cara yang sistematis dan biasa disebut dengan belajar dan beribadah. Belajar dan beribadah merupakan satu wadah untuk mengumpulkan satu dan beberapa banyaknya perbuatan (baik) yang dilakukan.

Djamaluddin Ancok dan Fuad Nashori Suroso dalam jurnal Iredho Fani Reza (2015) menjelaskan bahwa terdapat pandangan dari tokoh besar psikologi yang bernama James, beliau menerankan mengenai kegelisahan yang ada dalam jiwa dapat diatasi dengan meyakini adanya keberadaan dan campur tangan Tuhan (beriman). Keimanan akan memandu manusia dalam menjalankan kehidupannya dengan baik. Pernyataan ini kemudian memperkuat adanya penjelasan sebelumnya mengenai kebutuhan spiritual dapat dipenuhi dengan melakukan Ibadah. Ibadah yang dalam pelaksanaannya ditujukan untuk mendekatkan diri kepada Tuhan, telah membuktikan adanya kebutuhan manusia akan ketenangan dalam dirinya (Reza, 2015).

Berlanjut pada kajian belajar dan ibadah memiliki berbagai macam jenis atau cara. Belajar agama menjadi bagian dari ibadah. Sudah menjadi pengetahuan umum pula bahwa dalam pelaksanaan belajar di madrasah, terlebih sekolah madrasahnya juga dilaksanakan di tempat ibadah, maka sudah terbiasa terdapat struktur organisasi. Mengenai persepsi para aktivis yang melakukan kegiatannya di madrasah.

Memasuki pembahasan yang lebih meluas, aktivitas yang ada di madrasah akan dikaji dengan keadaan yang sedang terjadi saat ini. Pandemi COVID-19 yang merupakan sumber dari berbagai perubahan sosial sekaranng ini telah memberikan dampak besar bagi semua aspek kehidupan. Perubahan pada aspek sosial-politik, ekonomi, ketahanan serta hal lainnya menimbulkan adanya perbedaan dalam kegiatan yang dilakukan manusia saat ini. Seperti banyaknya kegiatan yang dibatasi dan memiliki aturan baru, manusia tidak lagi dapat secara bebas mengerjakan pekerjaanya. Hal inilah yang kemudian menimbulkan banyak problematika baik dalam unit terkecil keluarga hingga ke unit terbesar, yakni masyarakat bahkan masyarakat dunia.

Pemberitaan dari masuknya COVID-19 ke Indonesia ini mulanya masih bisa ditoleransi dengan adanya pengegahan tingkat satu dengan penggunaan masker dan pengurangan kontak fisik antar manusia. Namun semakin berjalannya waktu penyebaran yang tidak terkendali dan tentunya tidak terlihat, menunjukkan signifikansi angka dari pasien yang positif terjangkit COVID-19. Pemerintah selanjutnya secara bertahap menurunkan kebijakan melalui satu persatu surat edaran bagi masing-masing instansi dengan isi dari surat 
berupa perintah juga penangan yang sesuai dengan kondisi yang terjadi. Seperti pada bidang transportasi, pekerjaan, dan peribadatan penetapan keputusan untuk dilakukannya social distancing-physical distancing menjadi salah satu bentuk usaha pemerintah. Selebihnya ada pada peringatan untuk tidak lupa memulai dan membiasakan diri dengan perilaku hidup bersih, mencuci tangan dan membersihkan daerah sekitaran rumah dengan desinfektan.

Merujuk pada salah satu bidang yakni bidang peribadatan, pemberlakuan kebijakan pemerintah di Masa Pandemi' dituturkan oleh Menteri Agama (MENAG) Fachrul Razi, sebagai salah satu respon dari keinginan umat untuk beraktivitas. Isi daripada surat ini kemudian mencakup pengaturan protokol kesehatan guna sebagai syarat dari adanya pemberlakuan kembali beraktivitas. Serta kewajiban-kewajiban yang perlu dilaksanakan pengurus juga masyarakat yang ingin melakukan ibadah jamaah, dengan syarat kondisi wilayah secara nyata bebas dari adanya orang-orang yang diduga terjangkit COVID-19. Terlepas dari wilayah yang di-zona-kan, jika daerah yang termasuk golongan zona merah namun disekitarnya tidak benar-benar terdapat orang yang diduga atau bahkan sudah terjangkit maka diperbolehkan. Selanjutnya pembatasan jumlah jamaah yang akan beribadah hingga persyaratan lain yang harus dipenuhi warga daerah seperti meminta surat izin dari gugus tugas.

Setelah sebelumnya dibahas mengenai penjelasan umum mengenai aktivitas belajar dan kebijakan pemerintah, kali ini secara lebih spesifik, pembahasan akan berlanjut pada persepsi masyarakat. Kegiatan belajar yang dalam keseharian mengurusi dan mengembangkan pembangunan (akhlaq) masyarakat akan dimintai pendapatnya terkait dengan kebijakan yang diturunkan pemerintah. secara lebih jelas, aktivis masjid akan ditanyakan mengenai pandangannya. Tentunya dari adanya kebijakan ini terdapat sedikit banyaknya muncul pandangan yang berbeda dari masing-masing individu.

Namun terkait dengan batasan aturan pemerintah, dan kondisi di lapangan yang kurang memungkinkan, penelitian tidak dapat secara luas dilakukan dan hanya pihak atas (ketua) yang dimintai informasi. Sebagai seorang kepala pengurus pun tentunya memiliki kekuasaan lebih dalam menentukan dan mengurus organisasi di madrasah.

\section{B. TINJAUAN PUSTAKA}

Persepsi secara umum merupakan proses perolehan, penafsiran, pemilihan dan pengaturan informasi indrawi (Lystiana \& Hartono, 2015). Persepsi berlangsung pada saat seseorang meniram stimulus dari dunia luar yang ditangkap oleh organ-organ bantunya yang kemudian masuk ke dalam otak. Persepsi merupakan proses pencarian informasi untuk 
dipahami yang menggunakan alat pengindraan (Listyana, 2015). Sikap sendiri secara sederhana dapat dartikan dengan tindakan yang sebelumnya sudah di proses melalui otak dan merupakan respon terhadap rangsangan dari luar. Sikap sendiri dapat diartikan pula sebagai suatu bentuk dari sudut pandang seseorang terhadap hal-hal yang terjadi di sekitar. Sehingga presepsi tidaklah terlepas dari pemikiran yang dimiliki manusia.

Membahas mengenai sikap tidak lepas dari persepsi. Sementara persepsi sendiri tidak terlepas dari faktor-faktor yang memengaruhinya. Menurut Sarwono, faktor dari timbulnya persepsi ini terbagi menjadi lima, diantaranya; Pertama, perhatian. Faktor ini menunjukkan bahwa fokus yang dimiliki tidak secara langsung dapat ditujukan pada keseluruhan objek yang ada di sekitar dan hanya satu atau dua objek saja yang dijadikan tujuan. Adanya dua objek yang kemudian menjadi fokus ini, menimbulkan perbedaan dalam ber-persepsi. Kedua, ketersediaan secara matang terhadap respon yang akan muncul. Ketiga, adanya kondisi yang berbeda setiap waktunya, menyebabkan perbedaan kebutuhan. Dalam kasus persepsi ini tergantung daripada kebutuhan apa yang perlu lebih dulu dipenuhi. Keempat, nilai yang ada dalam masyarakat begitu berpengaruh pada persepsi. Kelima, kepribadian seseorang. tentunya kepribadian yang dimiliki masing-masing orang berbeda sehingga menimbulkan adanya pandangan yang berbeda pula (Sarwono, 2010).

Mengutip pendapat lain dari Muhammad Robin dalam jurnal Fatah Hanurawan (2015) terkait dengan faktor penyebab muculnya persepsi, menurutnya faktor dari persepsi sebagai berikut: Beberapa faktor utama yang memberi pengaruh terhadap pembentukan persepsi sosial seseorang dan faktor-faktor itu adalah faktor penerima (the perceiver), situasi (the situation), dan objek sasaran (the taget).

Faktor-faktor ini kemudian diperluas dengan menggunakan teori dari persepsi itu sendiri. Terdapat tiga teori dalam persepsi, diantaranya, teori atribusi, teori inferensi koresponden dan teori kovariasi. Pertama, teori atribusi mengkaji mengenai waktu dan proses yang akan didapatkan dari seorang individu melalui pertanyaan 'mengapa' atau penetuan dari konsep atribusi kausal yanng berarti penjelasan sebab-akibat dari dua kejadian (Santoso, 2014). Kedua, teori inferensi koresponden mengartikan penafsiran pada tingkah laku seseorang, tentang latar belakang dari tingkah laku tersebut berasal dari diri sendiri atau karena kondisi (Listyana, 2015). Ketiga, teori kovariasi yang menerangkan bahwa dalam pandangan suatu masyarakat terhadap suatu objek tidaklah sama. Suatu kejadian akan dikaji sebab-akibatnya secara bersamaan oleh masyarakat dengan pengolahan dan tentunya kesimpulan yang berbeda dari masing-masing individu dalam masyarakat. 
Mengutip penjelasan Winarno dalam jurnal Dian Fitriani Afifah dan Neneng Yani Yuningsih, dasarnya kebijakan tidak dapat dilepaskan dari berbagai komponen yang mengikatnya. Masyarakat yang dikenakan juga pihak yang menyediakan aturan, mendapati keterlibatan dengan kebijakan. Diteruskan dengan pengartian dari kebijakan itu sendiri, arti mengenai bentuk juga pengaplikasian dari konsep kebijakan ini disesuaikan dengan alasan dari seorang individu untuk mengkaji nya. Meski dengan pengertian berlandas pada alasan yang berbeda, konsep utama dari kebijakan ini terletak pada hal yang dilakukan bukan dari pemberlakuan batasan itu sendiri (Afifah \& Yuningsih, 2016).

Pendapat lain nan serupa mengenai kebijakan ini disampaikan oleh Nugroho masih dalam jurnal Dian Fitriani Afifah dan Neneng Yani Yuningsih, bahwasannya kebijakan dapat diartikan sebagai suatu hasil putusan dari pemerintah yang ada dalam negara guna mencapai tujuan yang diharapkan negara. Sedang, kebijakan publik adalah suatu cara yang dijalankan untuk menghantarkan masyarakat dari masyarakat awal ke masyarakat transisi hingga ke model masyarakat yang diharapakan.

Penjelasan tentang kebijakan lalu disimpulkan dengan satu pengertian besar yakni suatu aturan yang mengikat bagi siapapun baik yang ditujukan ataupun yang menujukan selama individu ada dalam cakupan wilayah yang diberlakukannya aturan tersebut. Aturan ini kemudian menjadi suatu cara yang dijalani guna mencapai tujuan yang diinginkan. Masyarakat yang menjadi objek dari kebijakan ini kemudian di sandingkan dengan berbagai aspek kehidupan. Khususnya pada kehidupan bernegara, karena aturan yang dimakasud dalam pengertian ini dibentuk, diberlakukan, diputuskan oleh negara. Aspek kehidupan yang ditujukan untuk diberlakukannya kebijakan ini adalah keseluruhan yang menyentuh nilai yang ada dalam masyarakat. pada penelitian ini nilai yang tersentuh ada pada aspek keagamaan, mengenai bagaimana kebijakan pemerintah dikaji dengan aktivitas yang ada dalam madrasah.

Memasuki variabel terakhir dalam penelitian ini, keadaan yang ada sekarang menunjukkan adanya perubahan yang begitu signifikan dalam kehidupan manusia. Bukan lagi menjadi permasalahan sebagian masyarakat, permasalahan ini telah mengguncang masing-masing individu di dunia. Munculnya suatu wabah penyakit yakni COVID-19 telah mengubah banyak tatanan kehidupan serta menimbulkan berbagai dampak. Dampak yang timbul kemudian tidak terlepas dari dampak positif dan negatif. Sebelum mengkaji mengenai wabah ini secara lebih jauh, maka akan dibahas dahulu mengenai pengertian wabah ini.

COVID-19 merupakan sebuah singkatan dari Corona Virus Desease -19 dimana memiliki arti Penyakit Virus Corona -19. Corona virus merupakan virus zoonotic, dimana ini 
diartikan dengan transmisi dari hewan ke manusia. Corona virus merupakan RNA virus, bersirkulasi di hewan, seperti unta, kucing, dan kelelawar. Hewan dengan corona virus dapat berkembang dan menginfeksi manusia (kasus MERS dan SARS serta kasus saat ini (2019 nCoV). Epidemi dua betacoronacirus yakni SARS dan MERS telah memakan 10.000 kasus (tingkat kematian 10\% untuk SARS dan 37\% untuk MERS). Kode genetik 2019 n-CoV mirip Corona virus SARS-like kelelawar, dan mungkin bermutasi sebelum menginfeksi manusia (Burhan, 2020).

Pengenalan dari COVID-19 ini selanjutnya dikaitkan dengan pembahasan yang sudah dijelaskan sebelumnya. Mulai dari variabel pertama yakni persepsi aktivis, dalam pengkajian pustaka pada variabel ini didapatkan suatu penjelasan bahwa persepsi diartikan sebagai suatu padangan pada objek sebab dari respon indrawi. Persepsi aktivis diartikan dengan pandangan dari seorang individu atau kelompok terhadap kegiatan yang dilakukan baik kegiatan yang berupa fisik ataupun non fisik pada objek yang diperhatikan.

\section{METODE PENELITIAN}

Paradigma penelitian ini menerapkan pendekatan kualitatif dengan metode deskriptif. Metode penelitian diperlukan guna mencapai informasi secara sistematis dan terperinci. Dalam penelitian diperlukan metode agar penelitian terarah dan tidak kemana-mana. Menurut Raco (2010), kata 'metode' dan 'metodologi' sering dicampuradukkan dan disamakan. Padahal keduanya memiliki arti yang berbeda. Kata 'metodologi' berasal dari kata Yunani 'methodologia' yang berarti 'teknik' atau 'prosedur'. Metodologi sendiri merujuk kepada alur pemikiran umum atau menyeluruh (general logic) dan gagasan teoritis (theoretic perspectives) suatu penelitian. Sedangkan kata 'metode' menunjuk pada teknik yang digunakan dalam penelitian seperti survey, wawancara dan observasi. Metode kualitatif merupakan salah satu jenis dari metode penelitian. Akan tetapi pada pendekatan ini "peneliti menjadi instrumen yang berusaha memahami dan menafsirakan makna suatu peristiwa interaksi tingkah laku manusia dalam situasi tertentu menurut perspektif peneliti sendiri.

Penelitian yang akan dikaji bertempat di daerah Sumberjaya Majalengka. Kajian mengenai persepsi aktivis siswa ini akan dibahas di wilayah tempat peneliti dengan tujuan untuk mencari pemecahan masalah yang ada di sekitar peneliti juga karena adanya keterbatasan dalam beraktivitas. Mengingat masih adanya pandemi terkait kegiatan yang diselenggarakan, kajian persepsi ini ditujukan untuk mendapatkan informasi lebih mengenai 
pandangan aktivis terhadap kegiatan yang sehari-harinya dilakukan terhadap pandemi yang sedang terjadi.

Selanjutnya adalah teknik yang digunakan dalam penelitian ini. Berbagai pertimbangan dilakukan dalam penggunaan teknik ini, hingga diputuskan bahwa teknik yang digunakan adalah wawancara. Teknik lain seperti observasi tidak dilakukan karena adanya penghalang dari faktor internal. Dalam pengertian yang dijelaskan oleh Lilya bahwa wawancara adalah proses mendapatkan informasi untuk dilakukannya penelitian dengan cara bertanya dan menjawab antar peneliti dan narasumber secara langsung dengan menggunakan instrumen berupa panduan wawancara (Susanti, 2016).

Seperti kutipan yang dijelaskan oleh Moleong dalam buku Jamaludin mengenai teknik wawancara, bahwa wawancara merupakan suatu bentuk dari interakasi yang dilakukan secara satu banding satu (individu ke individu) dengan nama pewawancara dan narasumber. Nama lain yang kemudian biasa disebut dengan informan dan peneliti.

Berlanjut pada analisis data, penelitian ini kemudian dikaji dengan menggunakan analisis kualitatif. Analisis kualitatif dijelaskan oleh Sugiyono dalam buku Adon Nasrullah Jamaluddin yakni mengenai data yang diperoleh. Dalam analisis kualitatif data yang diperoleh berasal dari berbagai sumber dengan menggunakan teknik triangulasi yang dilakukan secara terus menerus dan menghasilkan banyak dari beragam data.

Tujuan dari adanya penelitian yang dilakukan ini guna mendapatlan pandangan yang lebih luas mengenai aktivitas yang ada di madrasah pada masa pandemi ini. Aktivitas madrasah yang biasanya berlangsung dengan baik dan tanpa hambatan, harus sedikit banyaknya melakukan pembatasan pada kegiatan yang ada. Berangkat dari hal ini kemudian memasuki pada analisis pandangan aktivis madrasah terhadap kebijakan yang diturunkan oleh pemerintah. selebihnya penlitian ini dilakukan untuk memberikan kondisi terkini dari adanya kegiatan madrasah yang ada di wilayah peneliti.

Terkait dengan aturan-aturan yang diberlakukan bagi aktivis maupun siswa dari madrasah yang dijadikan tempat penelitian. Munculnya pandemi COVID-19 sepintas telah menjai latar belakang dari adanya aturan kebijakan yang disusun dan diberlakukan pemerintah pada aktivitas yang diselenggarakan. Sehingga secara keseluruhan dapat diketahui bahwa penelitian ini murni ditujukan untuk menganalisis secara rinci.

\section{HASIL DAN PEMBAHASAN}

Situasi saat ini yang mengharuskna masyarakat melakasanakan ibadah di rumah menjadikan sebagian orang harus memulai pembiasaan baru. Bagi aktivis madrasah terutama 
yang biasa melakukan banyak kegiatan di madrasah akan merasa sedikit berbeda karena kebiasaan yang perlu sedikit diubah. Situasi yang mendorong masyarakat beribadah di rumah ini kemudian bukan saja kebijakan semata-mata dikeluarkan pemerintah. Adanya dasar dari kebijakan Nabi Shallallahu Alaihi Wasallaam telah diberlakukan sejak dulu, karena pada zaman Nabi wabah seperti ini sudah pernah terjadi. Mengacu pada hadits Nabi Shallallahu Alaihi Wasallaam, yang menjelaskan mengenai ibadah di rumah saat terjadinya wabah semakin memperkuat kebijakan dari pemerintah saat ini.

Menurut pengelola madrasah terkait dengan adanya pembatasa sosial di wilayah sekitaran madrasah, bahwa sampai saat ini orang yang diperbolehkan untuk belajar di madrasah masih diprioritaskan warga sekitar saja. Berlanjut dengan adanya penyemprotan yang rutin dilakukan guna mencegah singgahnya virus serta alat lain seperti sabun cuci tangan dan handsanitizer sudah disediakan. Sampai saat ini dapat diketahui bahwa adanya edaran yang diturunkan pemerintah sudah dilaksanakan sesuai dengan protokol kesehatan yang dianjurkan.

Adapun pendapat dari wali siswa, bahwasannya terkait kebijakan dari surat edaran pemerintah ini dapat diterima baik dan sangat membantu dalam memberikan arahan kepada siswa untuk melakukan aktivitas lagi di madrasah. Adanya surat edaran yang baru ini membantu aktivis madrasah dalam memperkuat himbauan bagi siswa hendak melakukan belajar. Selebihnya, surat edaran ini dapat digunakan sebagai acuan dalam menjalankan aktivitas madrasah sekarang juga untuk kedepannya. Menjadi pengingat pada tiap kali adanya larangan dan aturan yang harus dipatuhi.

Menganalisis dari pernyataan yang sudah dijelaskan oleh Bapak SK juga informan terkait kebijakan di Masa Pandemi, bahwa persepsi yang timbul dari adanya kebijakan pemerintah ini adalah pandangan terhadap kebijakan yang dianggap sudah cukup bahkan sangat membantu. Adanya surat edaran yang diturunkan ini memberikan celah untuk memulai kembali aktivitas yang ada di dalam madrasah. Protokol yang dijelaskan dalam surat edaran tersebut sudah sangat jelas dan dapat dijalankan dengan baik oleh kepengurusan madrasah.

Menurut ustadz, terkait dengan adanya PSBB ini telah membantu dalam pembuatan konsep menjaga kesehatan di sekitaran daerah madrasah. Sehingga adanya surat edaran ini, seolah memperkuat pernyataan bahwa aktivitas di madrasah dapat dilaksanakan berdasar pada ketentuan. Kebijakan pemerintah ini memberi ruang siswa untuk melakukan aktivitas mengaji lagi di madrasah. 
Analisis dari pernyataan Bapak JK ini kemudian tidak berbeda jauh dengan pernyataan dari aktivis madrasah. Pada dasarnya, kebijakan yang dilakukan untuk kemaslahatan umat ini merupakan bentuk dari kepedulian pemerintah sehingga dapat diterima dengan baik. Maka dari itu, kebijakan PSBB dalam Mewujudkan Masyarakat Produktif dan Aman COVID di Masa Pandemi telah memberikan perspektif yang baik bagi siswa.

\section{Hambatan Pelaksanaan Kebijakan Pemerintah}

Bagi beberapa siswa masih nggan datang karena khawatir dengan adanya pandemi COVID-19 ini. Oleh karenanya pada aktivitas yang akan diadakan masih terhambat. Padahal dalam kebijakan Surat Edaran Nomor: SE. 15 Tahun 2020 tentang Panduan Penyelenggaraan Kegiatan Keagamaan di Rumah Ibadah dalam Mewujudkan Masyarakat Produktif dan Aman COVID di Masa Pandemi sudah dijelaskan bahwa aktivitas dapat dijalankan dengan baik namun dengan protokol kesehatan yang sudah dianjurkan.

Diteruskan dengan pendapat dari Ibu BR yang menjelaskan bahwa hambatan lain dari adanya ke-khawatiran dari sebagian siswa adalah jamaah lainnya yang mendorong untuk adanya kegiatan namun mengabaikan protokol kesehatan bahkan dari kebijakan yang sudah ada sebelumnya. Sehingga menimbulkan kekhawatiran bagi pengelola untuk mengadakan aktivitas di madrasah.

Pernyataan yang dijelaskan Bapak JK telah memberikan aspek baru dari adanya faktor hembatan pelaksanaan aktivitas yang ada di madrasah. Siswa yang mengabaikan protokol kesehatan ini merasa tidak apa-apa dengan adanya pandemi. Belajar tetap dijalankan, hanya saja pembatasan orang yang datang dari luar lebih diwaspadai. Dari persepsi tokoh masyarakat ini dapat ditarik satu analisis bahwa faktor utama dari adanya hambatan pelaksanaan aktivitas belajar adalah siswa sendiri. Adanya kekhwatiran dari berbagai latar belakang menimbulkan persepsi yang berbeda-beda pula serta menjadi bahan pertimbangan yang cukup sulit. Dalam konteks ini pelaksanaan aktivitas madrasah hingga saat ini belum dilaksanakan karena masih kuatnya persepsi siswa itu sendiri.

\section{Pengentasan Permasalahan Terkait Hambatan yang Terjadi}

Hambatan yang muncul tentunya beriringan dengan pengetasan, karena jika ada permasalahan tentunya dibutuhkan penyelesaian. Berikut merupakan pendapat dari narasumber terkait hambatan yang sebelumnya sudah dijelaskan. Hambatan yang terjadi pada siswa madrasah, selanjutnya akan entaskan dengan pandangan dari Bapak SJ. Selanjutnya 
oleh Ibu BR yang meneruskan pandangan dari Bapak SJ, bahwasannya pengarahan yang lebih ditekankan adalah kepada siswa yang ingin madrasah segera dibuka dan menjalankan aktivitas. Penekanan khusus pada siswa ini adalah pengawasan yang lebih tinggi agar tidak luput. Dorongan dari adanya penyegeraan pelaksanaan kegiatan madrasah banyak berasal dari siswa remaja yang baru berusia pubertas. Semangat menggebu untuk berkumpul dan menuntut ilmu menjadikan sebuah kekhawatiran tersendiri bagi pengelola.

\section{E. KESIMPULAN}

Siswa madrasah memiliki sikap patuh dan taat terhadap kebijakan pemerintah terkait dengan pembelajaran di madrasah. Meski ada Sebagian siswa dan masyarakat yang mengusulkan serta mendorong untuk dilakukannya pembelajaran secara terbatas, namun pada akhirnya mereka menyerahkan sepenuhnya kepada pengelola madarasah.

Sedanglan hambatan yang dominan berasal dari faktor internal siswa, yang menjadi point besar dari terhambatnya pelaksanaan aktivitas di madrasah dintaranya: (1) Adanya kekhwatiran sebagian siswa untuk mulai belajar kembali di madrasah (2) sebagian siswa yang tidak khawatir keluar rumah, mendorong segera dilaksanakannya aktivitas di madrasah namun mengabaikan protokol kesehatan yang sudah dihimbau pemerintah, sehingga dari hal ini menyebabkan kekhawatiran bagi pengelola (3) kebiasaan untuk berinteraksi menjadikan sulitnya menerapkan protokol kesehatan.

Penyelesaian permasalahan yang dapat dilakukan oleh aktivis siswa ini sepenuhnya kembali pada kesadaran bersama. Kesadaran dari pihak siswa untuk belajar membiasakan diri dengan kondisi, mengikuti arahan dari kebijakan yang sudah ditetapkan, serta tidak lupa untuk saling mengingatkan antar siswa. Sedangkan untuk pihak pengelola, terus melakukan himbauan dan menfaslitasi siswa dengan sebaik mungkin.

\section{DAFTAR PUSTAKA}

Afifah, D. F., \& Yuningsih, N. Y. (2016). Analisis Kebijakan Pemerintah tentang Pencegahan dan Penanganan Korban Perdagangan (Trafficking) Perempuan dan Anak di Kabupaten Cianjur. Jurnal Ilmu Pemerintahan, 2(2), 335-336.

Burhan, E. (2020). COVID-19 Gejala Klinis dan Pengobatannya. 2020. Proceedings of Departemen Pulmonologi dan Kedokteran Respirasi FKUI RS Persahabatan" (Jakarta: 28 Januari 2020).

Hanurawan, F. (2015). Psikologi Sosial: Suatu Pengantar. Bandung: Remaja Rosdakarya. 
Jamaludin, A. N. (2018). Modul Pembelajaran: Metode Penelitian Sosial. Bandung: Pustaka Setia

Kurniawan, S. (2014). Masjid dalam Lintasan Sejarah Umat Islam. Jurnal KhatulistiwaJournal of Islamic Studies, 4(2).

Kustana \& Setiawan, C. (2020). Resolusi Konflik Sistem Pengelolaan Irigasi Pertanian di Pedesaan. Jurnal Pembangunan Sosial, 3(1).

Listyana, R., \& Hartono, Y. (2015). Persepsi dan Sikap Masyarakat Terhadap Penanggalan Jawa dalam Penentuan Waktu Pernikahan. Jurnal Agastya, 5(1).

Muhaemin. (1991). Konsep Pendidikan Islam Telaah Komponen Dasar Kurikulum. Solo: Romadhoni.

Muhaemin \& Mujib, A. (1991). Pemikiran Pendidikan Islam. Bandung: Trigendakarya.

Mukharom \& Arafik, H. (2020). Kebijakan Nabi Muhammad SAW Menangani Wabah Penyakit Menular dan Implementasinya dalam Konteks Menanggulangi Coronavirus COVID-19. Jurnal Sosial dan Budaya Syar'i, 7(3).

Raco. (2010). Metode Penelitian Kualitatif: Jenis, Karakteristik dan Keunggulannya. Jakarta: Gramedia Widiasarana Indonesia.

Reza, I. F. (2015). Evektifitas Pelaksanaan Ibadah dalam Upaya Mencapai Kesehatan Mental. Jurnal Psikologi Islami, 1(1).

Santoso, S. (2014). Teori-Teori Psikologi Sosial. Bandung: Refika Aditama.

Sarwono, S. W. (2010). Pengantar Psikologi Umum. Jakarta: Rajawali Pers.

Susanti, L. (2016). Modul Metode Penelitian. Malang: Departemen Riset Teknologi dan Pendidikan Tinggi.

Syah, M. (1995). Psikologi Pendidikan suatu Pendekatan Baru. Bandung: Remaja Rosda Karya.

West, M. A. (1997). Developing Creativity in Organizations, USA: British Psychological Society.

Zaini, A. (2016). Manajemen Dakwah Remaja Ikatan Masjid Baiturrohman (IRMABA) di Desa Puncakwangi Kecamatan Puncakwangi Kabupaten Pati. TADBIR: Jurnal Manajemen Dakwah, 1(2). 